Article

\title{
Cordidepsine is A Potential New Anti-HIV Depsidone from Cordia millenii, Baker
}

\author{
Rostanie Dongmo Zeukang ${ }^{1,2}$, Xavier Siwe-Noundou ${ }^{3, * \mathbb{C}}$, Maurice Tagatsing Fotsing ${ }^{1}$, \\ Turibio Tabopda Kuiate ${ }^{1}$, Joseph Tanyi Mbafor ${ }^{1}$, Rui W. M. Krause ${ }^{3}$ (D), \\ Muhammad Iqbal Choudhary ${ }^{2}$ and Alex de Théodore Atchadé ${ }^{1 \text {,* }}$ \\ 1 Department of Organic Chemistry, University of Yaoundé I, Faculty of Science, \\ P.O. Box 812 Yaoundé, Cameroon \\ 2 International Center for Chemical and Biological Sciences, H.E.J Research Institute of Chemistry, \\ University of Karachi, Karachi-75270, Pakistan \\ 3 Department of Chemistry, Rhodes University, Grahamstown 6140, South Africa \\ * Correspondence: xavsiw@gmail.com or x.siwenoundou@ru.ac.za (X.S.-N.); alexiode@yahoo.fr (A.d.T.A.)
}

Received: 21 June 2019; Accepted: 23 August 2019; Published: 3 September 2019

Abstract: Chemical investigation of Cordia millenii, Baker resulted in the isolation of a new depsidone, cordidepsine (1), along with twelve known compounds including cyclooctasulfur (2), lup-20(29)-en-3-triacontanoate (3), 1-(26-hydroxyhexacosanoyl)glycerol (4), glyceryl-1-hexacosanoate (5) betulinic acid (6), lupenone (7), $\beta$-amyrone (8), lupeol (9), $\beta$-amyrin (10), allantoin (11), 2'-(4-hydroxyphenyl)ethylpropanoate (12) and stigmasterol glycoside (13). Hemi-synthetic reactions were carried out on two isolated compounds (5 and 6) to afford two new derivatives, that is, cordicerol A (14) and cordicerol B (15), respectively. The chemical structures of all the compounds were established based on analysis and interpretation of spectroscopic data such as electron ionization mass spectrometry (EI-MS), high resolution electrospray ionization mass spectrometry (HR-ESI-MS), fast atom bombardment mass spectrometry (FAB-MS), one dimension and two dimension nuclear magnetic resonance (1D and 2D-NMR) spectral data as well as X-ray crystallography (XRC). Lupeol ester derivatives [Lup-20(29)-en-3-triacontanoate (3)], monoglycerol derivatives [1-(26-hydroxyhexacosanoyl)glycerol (4) and glyceryl-1 hexacosanoate (5)] were isolated for the first time from Cordia genus while sulfur allotrope [cyclooctasulfur (2)] was isolated for the first time from plant origin. Biological assays cordidepsine (1) exhibited significant anti-HIV integrase activity with $\mathrm{IC}_{50}=4.65 \mu \mathrm{M}$; EtOAc extract of stem barks, EtOAc fraction of roots and leaves were not toxic against $3 \mathrm{~T} 3$ cells.

Keywords: Cordia millenii; isolation; depsidone; cordidepsine; monoglycerol; allotrope sulfur; anti-HIV activity

\section{Introduction}

Acquired Immune Deficiency Syndrome (AIDS) is one of the major viral infections ravaging the world; around 76.1 million people have been infected since the first report in 1981 [1]. According to the report of the Cameroon Population Based HIV Impact Assessment (CAMPHIA) in 2018, viral prevalence in Cameroon is 3.4\% [2] and about 37 million people around the world are currently living with the infection [1]. The absence of vaccines and associated resistance of virus to antiretroviral drugs [1] have contributed to the impairment of most patient's defense system by opportunistic bacterial infections such as tuberculosis and other bacterial pneumonia infections [3].

Bacterial infections are one of the major causes of morbidity and mortality in developing countries [4]. Though antimicrobial drugs have improved the healing of some patients with bacterial 
infections and reduce mortality, increasing microbial resistance is a major concern [4]. The resistance to treatment may be due to the new interference mechanisms with antimicrobial activity and the emergence of some conditions that weaken the patient's innate immunity [4]. Since antimicrobial drugs remain necessary for the treatment of many diseases, it is imperative to search for new and efficient ones that may reduce bacterial resistance. The current work identified potential antibacterial agents from Cordia millenii.

Cordia millenii, Baker is a tree belonging to the Boraginaceae family. It is widely distributed in tropical Africa and is usually planted in West Africa, where various parts are used in traditional medicine [5]. The seed powder, for example, is mixed with palm oil and applied externally to treat ringworm [5]. In Cameroon and other West African countries, decoctions of leaves are applied to expulse worms, to treat coughs, asthma and the common cold. The concoction of its leaves with Centella asiatica is used to treat children's convulsions [6]. A previous phytochemical study of the heartwood of Cordia millenii led to the isolation of terpenoids and benzoquinones (Cordichromes A-F) [7]. A general phytochemical screening analysis revealed the presence of phenolic compounds, alkaloids, terpenoids, steroids, glycosides, flavonoids, tannins and saponins [8]. In addition, a number of alkaloid compounds in C. millenii are proposed as a basis for developing antimalarial and antibacterial drugs [8]. Moreover, previous studies showed that many species of Cordia are used as antiviral drugs. In this instance, the aqueous leaf extract of Cordia spinescens had demonstrated potential HIV reverse transcriptase enzyme inhibition with $\mathrm{IC}_{50}$ values of 6-8 $\mu \mathrm{g} / \mathrm{mL}$ [9]. Several plants of the Cordia genus are used for antibacterial, antioxidant, anti-inflammatory, antidiabetic, antitumor purposes and as an analgesic and for wound healing [9]. We report here the isolation and structural identification of fifteen compounds from C. millenii and some hemi-synthetic derivatives. The anti-HIV, cytotoxicity and antibacterial activities of crude extract and isolated compounds were investigated to support the traditional use of C. millenii for the treatment of infectious diseases.

\section{Results}

\subsection{Identification of Isolated Compounds}

The extracts of Cordia millenii, Baker (leaves, stem barks and roots) were submitted to repeated column chromatography to afford one new depsidone (1), together with twelve known compounds (Figure 1). These known compounds include: Cyclooctasulfur (2), lup-20(29)-en-3-triacontanoate (3) [10], lupeol ester (reported for the first time from Cordia genus), 1-(26-hydroxyhexacosanoyl)glycerol (4) [11], glyceryl-1-hexacosanoate (5) [12], which are monoglycerides and this is the first report of monoglycerol from Cordia genus. The other known compounds are betulinic acid (6) [13], lupenone (7) [14], $\beta$-amyrone (8) [15], lupeol (9) [16], $\beta$-amyrin (10) [17], allantoin (11) [18], 2'-(4-hydroxyphenyl)ethylpropanoate (12) [19] and stigmasterol glycoside (13) [20]. The chemical structures of the hemi-synthetic derivatives, that is, Cordicerol A (14) and Cordicerol B (15), are also presented in Figure 1. 
<smiles>Cc1cc2c(c(C)c1O)Oc1c(C=O)c(O)c(I)c(Br)c1C(=O)O2</smiles>

Cordidepsine (1)<smiles>S1SSSSSSS1</smiles>

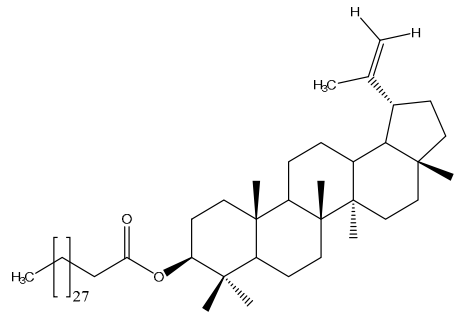

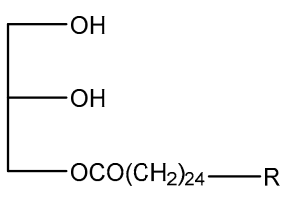

R: $\mathrm{CH}_{2} \mathrm{OH}$ : 1-(26-hydroxyhexacosanoyl)glycerol (4) $\mathrm{R}: \mathrm{CH}_{3}$ : Glyceryl-1-hexacosanoate (5)

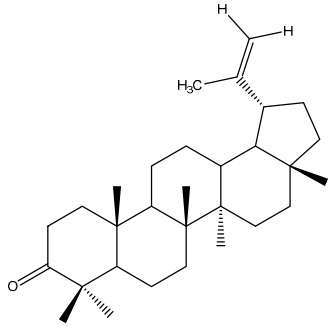

Lupenone (7)

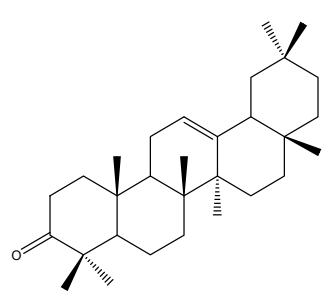

$\beta$-amyrone (8)

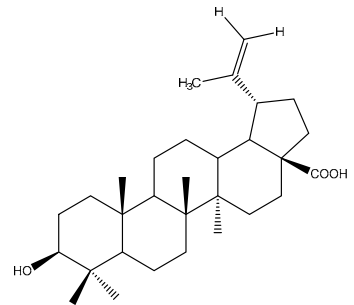

Betulinic acid (6)

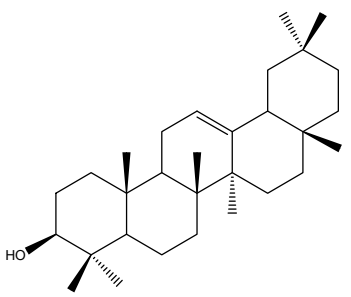

$\beta$-amyrin (10)<smiles>NC(=O)N[C@@H]1NC(=O)NC1=O</smiles>

Allantoin (11)

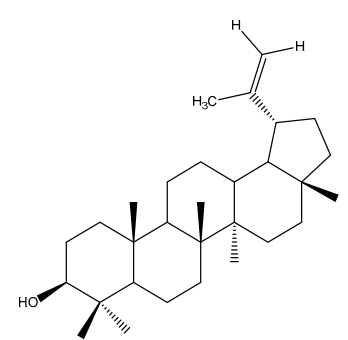

Lupeol (9)

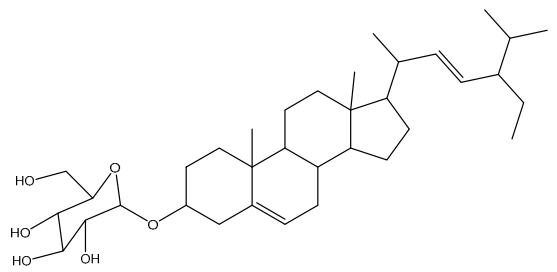

Stigmasterol glycoside (13)

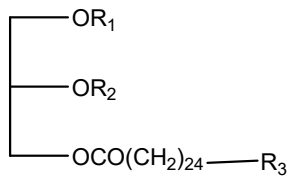

$\mathrm{R}_{1}=\mathrm{R}_{2}: \mathrm{COCH}_{3} / \mathrm{R}_{3}: \mathrm{CH}_{2} \mathrm{OCOCH}_{3}$ : Cordicerol A (14) $\mathrm{R}_{1}=\mathrm{R}_{2}: \mathrm{COCH}_{3} \mathrm{R}_{3}: \mathrm{CH}_{3}$ : Cordicerol B (15)

Figure 1. Chemical structures of compounds.

Compound 1 was isolated as a white powder from $n$-hexane/EtOAc $(6: 4, v / v)$. Its molecular formula was established as $\mathrm{C}_{17} \mathrm{H}_{14} \mathrm{O}_{7}$, on the basis of the HR-ESI-MS at $m / z 376.4972$ [M $\left.+2 \mathrm{Na}\right]^{+}$ (calcd $\mathrm{C}_{17} \mathrm{H}_{14} \mathrm{O}_{7} \mathrm{Na}_{2}, 376.0535$ ), accounting for 11 double bond equivalents. The ${ }^{13} \mathrm{C}$ nuclear magnetic 
resonance (NMR) spectrum (Table 1) of 1 exhibited the presence of 17 carbon signals, including one methoxy carbon at $\delta_{\mathrm{C}} 56.3\left(\mathrm{OCH}_{3}\right)$, two aromatic methyl signals at $\delta_{\mathrm{C}} 21.7(\mathrm{C}-12)$ and $9.8(\mathrm{C}-13)$. In addition, we observed in the downfield shield, two aromatic methine signals at $\delta_{C} 117.4(\mathrm{C}-2)$ and 107.7 (C-9). This spectrum also revealed the presence of ten aromatic quaternary carbons, of which six oxygenated appeared at $\delta_{C} 164.0$ (C-3), 164.8 (C-4a), 142.5 (C-5a), 161.0 (C-9a), 143.4 (C-6), 154.7 (C-8) and the rest at $\delta_{C} 152.7(\mathrm{C}-1), 110.9(\mathrm{C}-4), 122.8(\mathrm{C}-7), 111.9(\mathrm{C}-11 \mathrm{a})$. The other signals were attributed to the lactone carbonyl at $\delta_{C} 166.1$ (C-11) and aldehyde function at $\delta_{C} 193.9(\mathrm{C}-14)$. These data were similar to those of related depsidones previously isolated from several microorganisms [21-24] and some species of Garcinia genus [25]. The ${ }^{1} \mathrm{H}$ NMR spectrum (Table 1) confirmed the presence of two aromatic singlets at $\delta_{\mathrm{H}} 6.85(1 \mathrm{H}, s, \mathrm{H}-2)$ and $\delta_{\mathrm{H}} 7.08(1 \mathrm{H}, \mathrm{s}, \mathrm{H}-9)$, suggesting two penta-substituted aromatic rings. The ${ }^{1} \mathrm{H}$ NMR also displayed two aromatic methyl signals at $\delta_{\mathrm{H}} 2.45(3 \mathrm{H}, \mathrm{s}, \mathrm{H}-12), 2.19$ $(3 \mathrm{H}, \mathrm{s}, \mathrm{H}-13)$, one methoxy group signal at $\delta_{\mathrm{H}} 3.85\left(3 \mathrm{H}, \mathrm{s}, \mathrm{OCH}_{3}\right)$ and the signal of aldehyde proton at $\delta_{\mathrm{H}} 10.43(1 \mathrm{H}, s, \mathrm{H}-14)$. The HMBC correlations (Figure 2$)$ of $\mathrm{H}-2\left(\delta_{\mathrm{H}} 6.85\right)$ to C-3 $\left(\delta_{\mathrm{C}} 164.0\right), \mathrm{C}-14$ $\left(\delta_{C} 193.5\right), C-11 a\left(\delta_{C} 111.9\right), C-12\left(\delta_{C} 21.7\right)$ suggested that the aldehyde function and the aromatic methyl at $\delta_{C} 21.7$ are located on the same aromatic ring (I). The position of the aldehyde function was also supported by the correlation of $\mathrm{H}-14\left(\delta_{\mathrm{H}} 10.4\right)$ with $\mathrm{C}-4\left(\delta_{\mathrm{C}} 110.9\right)$ and $\mathrm{C}-4 \mathrm{a}\left(\delta_{\mathrm{C}} 164.8\right)$, indicating that the aldehyde function is located at C-4 $\left(\delta_{C} 110.9\right)$ as evidenced by the above HMBC correlations. In addition, the substituents of the second aromatic ring (II) were identified through HMBC correlations of H-9 $\left(\delta_{\mathrm{H}} 7.08\right)$ to C-5a $\left(\delta_{C} 142.5\right), \mathrm{C}-7\left(\delta_{\mathrm{C}} 122.8\right), \mathrm{C}-8\left(\delta_{\mathrm{C}} 154.7\right), \mathrm{C}-11\left(\delta_{\mathrm{C}} 166.1\right)$ and C-13 $\left(\delta_{C} 9.8\right)$, as well as the HMBC correlations of H-13 to C-6; C-7; and C-8. The assignments of protons to carbon were further confirmed on the HSQC spectrum. However, the aldehyde correlations were shifted to around $30 \mathrm{ppm}$ and the proton at $\delta_{\mathrm{H}} 10.43$ (Figure S5, Supplementary materials) due to spectral "folding" of aldehyde signal resulting from a poorly selected ${ }^{13} \mathrm{C}$ spectral width applied to reduce the recording time [26]. The required degrees of unsaturation suggested that the aromatic rings (I) and (II) should be linked by an ether and an ester bridge confirming a depsidone skeleton with a seven-membered ring (III) [23]. The proposed structure was reinforced by a NOESY experiment which revealed the correlations (Figure 2) between the methoxy group $\left(\delta_{\mathrm{H}} 3.85\right)$ and H-9 $\left(\delta_{\mathrm{H}}\right.$ 7.08), between both methyl groups $\left(\delta_{\mathrm{H}} 2.19\right.$ and $\left.\delta_{\mathrm{H}} 2.45\right)$, between aromatic proton at $\delta_{\mathrm{H}}$ $6.85(\mathrm{H}-2)$ and methyl protons at $\delta_{\mathrm{H}} 2.45(\mathrm{H}-12)$; and between both aromatic protons $\left(\delta_{\mathrm{H}} 6.85\right.$ and $\delta_{\mathrm{H}}$ 7.08). From an analysis of all the above data, the structure of compound 1 was established as 3,6-dihydroxy-8-methoxy-1,7-dimethyl-11-oxo-11H-dibenzo[b,e] [1,4]dioxepine-4 carbaldehyde which is a new depsidone to which the trivial name Cordidepsine was assigned. To the best of our knowledge, depsidone metabolite is reported here for the first time in the Boraginaceae family and Cordia genus.
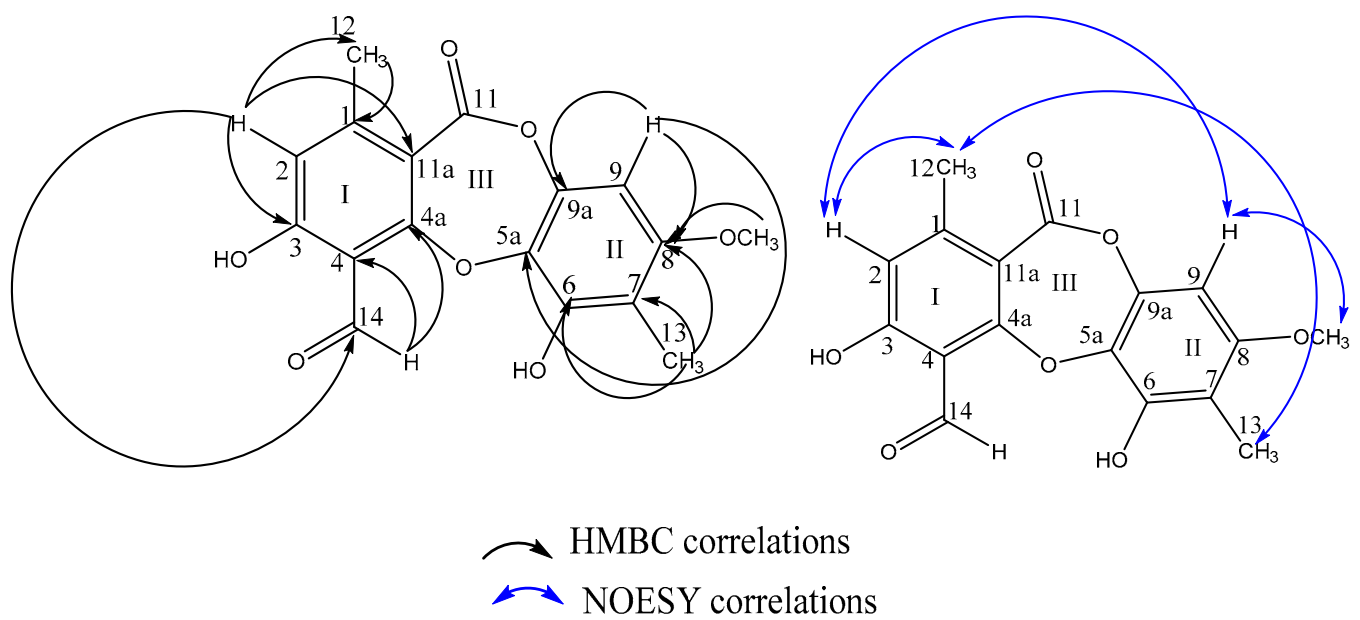

Figure 2. Selected 2D-NMR correlations of Cordidepsine. 
Compound 2 was isolated as a yellow powder from ethyl acetate fraction of roots. Its HR-EI-MS spectrum exhibited a molecular ion peak at $m / z 255.7766$, suggesting the molecular formula of $S_{8}$ (calcd 255.7766), which is an allotrope of sulfur. It also presented a difference of $\mathrm{m} / \mathrm{z} 32$ between two consecutive peaks on mass spectral data, suggesting a ${ }^{32} S$ nature of the sulfur. The ${ }^{32} \mathrm{~S}-\mathrm{NMR}$ spectrum was not performed due to the insufficient quantity of isolated sample but its X-ray (Figure 3) was performed and compound 2 was identified as cyclooctasulfur [27]. Cyclooctasulfur was previously reported from a fungal source [28]. To the best of our knowledge, this is the first report of cyclooctasulfur isolated from a plant source.

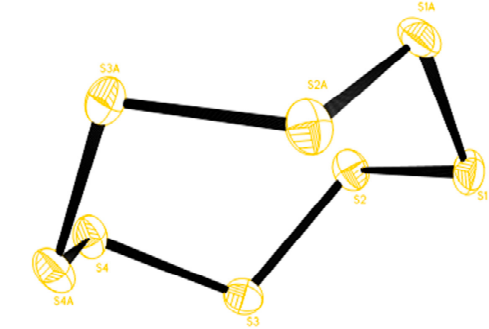

Figure 3. X-ray representation of cyclooctasulfur.

\subsection{Identification of Hemzi-Synthetic Derivatives}

The acetylation reaction (Scheme 1) of isolated compounds 4 and 5 led to the synthesis of new derivatives, that is, cordicerol A (14) and cordicerol B (15), respectively.

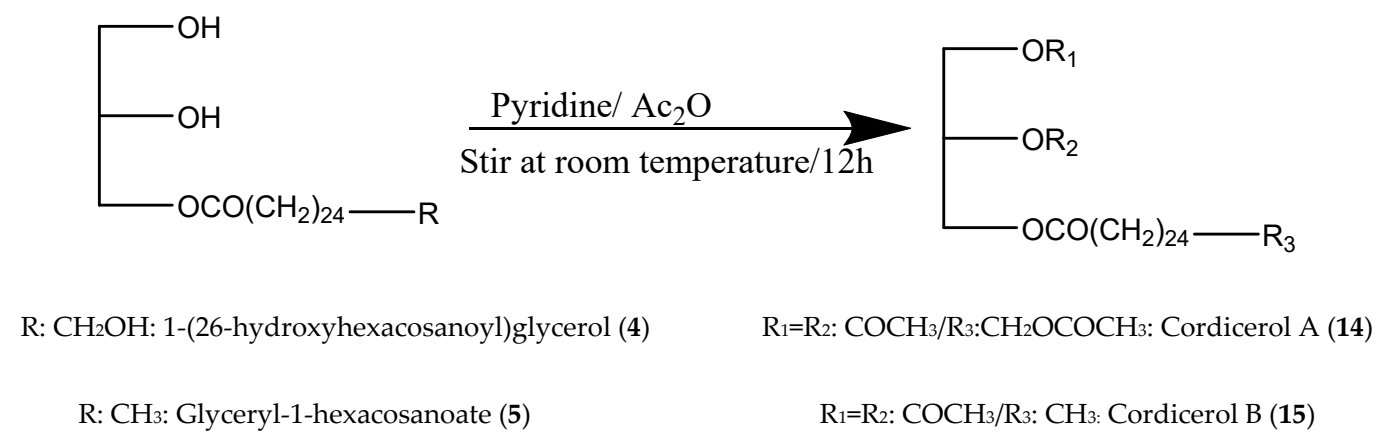

Scheme 1. Acetylation reaction of compounds 4 and 5.

Compound 14 was obtained as a white powder from an acetylation reaction of the hydroxyl groups of compound 4 [1-(26-hydroxyhexacosanoyl)glycerol]. The HR-ESI-MS spectrum (positive-ion mode) exhibited a pseudo-molecular ion $[\mathrm{M}+\mathrm{H}]^{+}$peak at $\mathrm{m} / \mathrm{z} 613.4672$, suggesting the molecular formula of $\mathrm{C}_{35} \mathrm{H}_{64} \mathrm{O}_{8}$ (calcd 613.4679). The ${ }^{1} \mathrm{HNMR}$ spectrum (Table 2) revealed signals at $\delta_{\mathrm{H}} 4.03 \mathrm{ppm}$ $(2 \mathrm{H}, t, J=6.7 \mathrm{~Hz}, \mathrm{H}-26)$ attributable to methylene linked to oxygen of ester function; at $\delta_{\mathrm{H}} 2.29$ $(2 \mathrm{H}, t, \mathrm{H}-2)$ assigned to a methylene at $\alpha$ position of carbonyl (C-1) and at $\delta_{\mathrm{H}} 2.02(3 \mathrm{H}, s, \mathrm{H}-2$ '); 2.05 $\left(3 \mathrm{H}, \mathrm{s}, \mathrm{H}-4^{\prime \prime}\right)$ and $2.06\left(3 \mathrm{H}, \mathrm{s}, \mathrm{H}-6^{\prime \prime}\right)$, attributable to three methyl groups linked to carbonyl functions, resulted from the acetylation reaction. A broad signal at $\delta_{\mathrm{H}} 1.23$ was assigned to the protons of the methylene chain. The ${ }^{13} \mathrm{C}$ NMR spectrum (Table 2) displayed signals of four ester groups at $\delta_{C} 173.3$ (C-1), 171.2 (C-1"), 170.5 (C-5") and 170.1 (C-3"). The structure elucidation was established based on COSY correlations (Figure 4$)$ between methine proton at $\delta_{\mathrm{H}} 5.23\left(\mathrm{H}-2^{\prime}\right)$ with methylene at $\delta_{\mathrm{H}} 4.13$ $\left(\mathrm{H}-1^{\prime}\right)$ and 4.28 (H-3'). The structure elucidation was also facilitated by HMBC correlations (Figure 4) between the methine (H-2') with carbonyl group at $\delta_{\mathrm{C}} 170.1$ (C-3"). HMBC correlations were also observed between methylenes at $\delta_{\mathrm{H}} 4.13\left(\mathrm{H}-1^{\prime}\right), 4.28\left(\mathrm{H}-3^{\prime}\right)$ and $\mathrm{C}-1\left(\delta_{\mathrm{C}} 173.3\right)$ and $\mathrm{C}-5^{\prime \prime}\left(\delta_{\mathrm{C}} 170.5\right)$ respectively, as well as between $\mathrm{H}-26\left(\delta_{\mathrm{H}} 4.03\right)$ and $\mathrm{C}-1^{\prime \prime}\left(\delta_{\mathrm{C}} 171.2\right)$. The 2D-NMR correlations (Figure 4$)$ were very important for the determination of the proposed structure. The analysis of $1 \mathrm{D}$ and 2D-NMR, 
HR-ESI-MS data as well as comparison with literature [11] led to the identification of compound $\mathbf{1 4}$ as a new derivative of 1-(26-hydroxyhexacosanoyl) glycerol, reported here for the first time. A trivial name-Cordicerol A-was given to compound 14 .

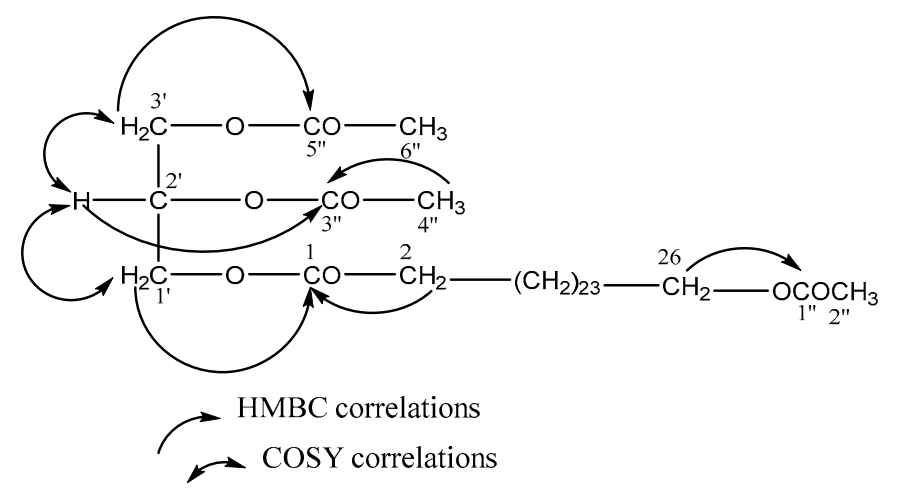

Figure 4. COSY and HMBC correlations for Cordicerol A.

Compound 15 was obtained as a white powder following an acetylation reaction on the hydroxyl groups of compound 5 (glyceryl-1-hexacosanoate). The HR-ESI-MS spectrum (positive-ion mode) of compound 15 exhibited a pseudo-molecular ion $[\mathrm{M}+\mathrm{Na}]^{+}$peak at $m / z 577.4448$, suggesting the following molecular formula $\mathrm{C}_{33} \mathrm{H}_{62} \mathrm{O}_{6}$ (calcd 577.4446, $\mathrm{C}_{33} \mathrm{H}_{62} \mathrm{O}_{6} \mathrm{Na}$ ). The comparison of the spectral data of compounds 14 and 15 (Table 2) shows that the two compounds have the same fatty acyl glycerol skeleton but the ${ }^{1} \mathrm{H}-\mathrm{NMR}$ spectrum of compound $\mathbf{1 5}$ displayed, moreover, a signal of terminal methyl group protons at $\delta_{\mathrm{H}} 0.86(3 \mathrm{H}, t, J=7 \mathrm{~Hz}, \mathrm{H}-26)$ and signals of two methyl group linked to carbonyl groups resulted from reaction at $\delta_{\mathrm{H}} 2.06\left(3 \mathrm{H}, s, \mathrm{H}-2^{\prime \prime}\right)$ and $2.05\left(3 \mathrm{H}, \mathrm{s}, \mathrm{H}-4^{\prime \prime}\right)$ instead of three, as observed in compound 14. The ${ }^{13} \mathrm{C}$ NMR spectrum of compound $\mathbf{1 5}$ exhibited a signal of three ester groups at $\delta_{C} 173.3(\mathrm{C}-1), 170.2\left(\mathrm{C}-1^{\prime \prime}\right)$ and $170.5\left(\mathrm{C}-3^{\prime \prime}\right)$. The presence of a terminal methyl group was confirmed by a signal at $\delta_{C} 14.1$. The analysis of $1 \mathrm{D}$ and 2D-NMR (Figure 5), HR-ESI-MS data as well as comparison with literature [12] led to the identification of compound $\mathbf{1 5}$ as a new derivative of glyceryl-1-hexacosanoate, reported here for the first time. A trivial name-Cordicerol B-was given to compound 15.

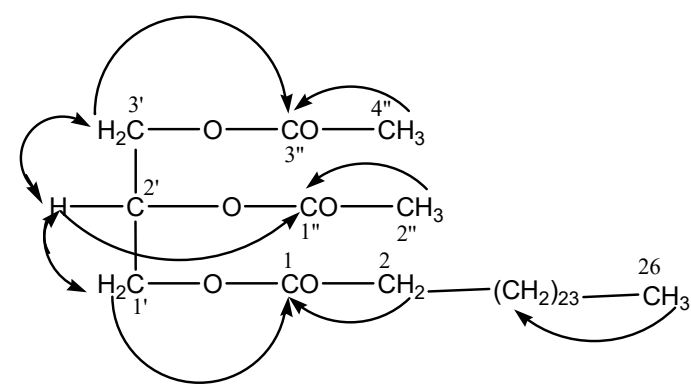

HMBC correlations

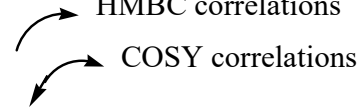

Figure 5. COSY and HMBC correlations for Cordicerol B. 
Table 1. Nuclear magnetic resonance (NMR) spectroscopic data $\left(600 \mathrm{MHz}\right.$ for ${ }^{1} \mathrm{H}$ and $150 \mathrm{MHz}$ for ${ }^{13} \mathrm{C}$, in DMSO) of compound $\mathbf{1}(\delta$ in ppm).

\begin{tabular}{ccccc}
\hline Position & $\boldsymbol{\delta}\left({ }^{\mathbf{1}} \mathbf{H}\right)($ mult $)$ & $\boldsymbol{\delta}\left({ }^{\mathbf{1 3}} \mathbf{C}\right)$ & HMBC & NOESY \\
\hline 1 & - & 152.7 & - & - \\
2 & $6.85(1 \mathrm{H}, s)$ & 117.4 & C-3, C-11a, C-12, C-14 & H-9 \\
3 & - & 164.0 & - & - \\
4 & - & 110.9 & - & - \\
$4 \mathrm{a}$ & - & 164.8 & - & - \\
$5 \mathrm{a}$ & - & 142.5 & - & - \\
6 & - & 143.4 & - & - \\
7 & - & 122.8 & - & - \\
8 & - & 154.7 & - & - \\
9 & $7.08(1 \mathrm{H}, s)$ & 107.7 & $\mathrm{C}-5 \mathrm{a}, \mathrm{C}-7, \mathrm{C}-8, \mathrm{C}-11, \mathrm{C}-13$ & $\mathrm{H}-2, \mathrm{OCH}$ \\
$9 \mathrm{a}$ & - & 161.0 & - & - \\
11 & - & 166.1 & - & - \\
$11 \mathrm{a}$ & - & 111.9 & - & - \\
12 & $2.45(3 \mathrm{H}, s)$ & 21.7 & $\mathrm{C}-1, \mathrm{C}-2, \mathrm{C}-4 \mathrm{a}, \mathrm{C}-11 \mathrm{a}$ & $\mathrm{H}-13$ \\
13 & $2.19(3 \mathrm{H}, s)$ & 9.8 & $\mathrm{C}-6, \mathrm{C}-7, \mathrm{C}-8$ & $\mathrm{H}-12$ \\
14 & $10.43(1 \mathrm{H}, s)$ & 193.9 & $\mathrm{C}-4, \mathrm{C}-4 \mathrm{a}$ & - \\
$\mathrm{OCH}_{3}$ & $3.83(3 \mathrm{H}, s)$ & 56.3 & $\mathrm{C}-8$ & $\mathrm{H}-9$ \\
\hline
\end{tabular}

Table 2. NMR spectroscopic data (500 MHz for ${ }^{1} \mathrm{H}$ and 125 and $200 \mathrm{MHz}$ for ${ }^{13} \mathrm{C}$, in $\mathrm{CDCl}_{3}$ ) of compounds 14 and 15 ( $\delta$ in ppm and $J$ in $\mathrm{Hz}$ ).

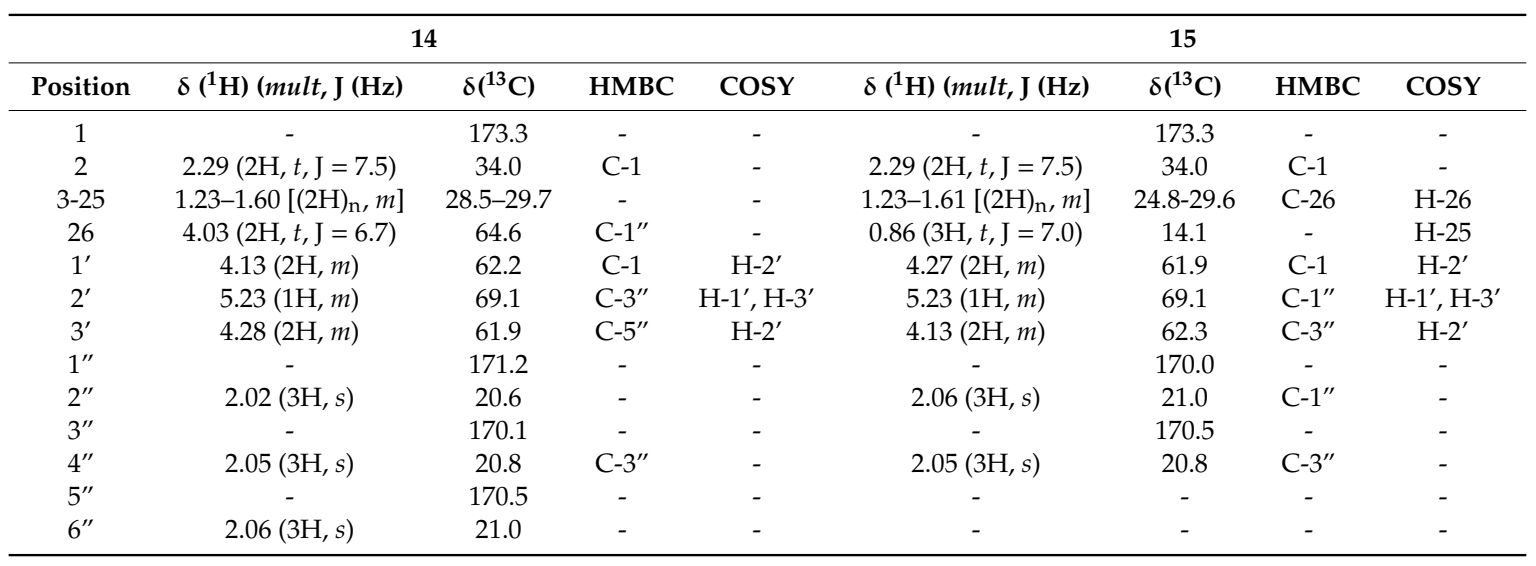

\subsection{Biological activities}

Many species of Cordia are used in traditional medicine for the treatment of various infectious diseases such as malaria, diarrhea, dysentery, stomach pain, fever, blood disorder and syphilis [9]. Due to time constraints, small amounts of samples and availability of assays, antibacterial, cytotoxicity activities of leaves, stem barks and roots crude extracts, fractions and anti-HIV activity of only some isolated compounds were investigated in this study.

\subsubsection{Anti-HIV Activity}

Cordidepsine (1) and allantoin (11) were tested in vitro for their inhibitory effect against HIV-1 Integrase. Cordidepsine (1) exhibited promising activity with an $\mathrm{IC}_{50}$ value of $4.65 \mu \mathrm{M}$. Chicoric acid was used as a reference HIV-1 Integrase drug $\left(\mathrm{IC}_{50}=0.33 \mu \mathrm{M}\right)$. Allantoin $(\mathbf{1 1})$ also displayed weak activity with an $\mathrm{IC}_{50}$ value of $412.94 \mu \mathrm{M}$ (Table 3 ). The activity of compound 1 can be justified by the fact that previous biological studies revealed that depsidones are potential antiviral agents [24]. Furthermore, with reference to compound 1, previous studies showed that an aromatic moiety next to (at least) two adjacent oxygens appears to be a structural element that is essential for activity against HIV-1 integrase [29]. In addition, the activity can also be explained by the presence of aromatic hydroxyl 
groups which have been reported to be effective inhibitors of integrase [29,30]. Moreover, previous studies showed that many species of Cordia are used as antiviral. To this instance, the leaves water extract of Cordia spinescens was demonstrated to be a potential inhibitor on HIV reverse transcriptase enzyme with $\mathrm{IC}_{50}$ values of $6-8 \mu \mathrm{g} / \mathrm{mL}$ [27].

Table 3. Anti-HIV-1 integrase activity $\left(\mathrm{IC}_{50}\right.$ in $\left.\mu \mathrm{M}\right)$ of isolated compounds $\mathbf{1}$ and $\mathbf{1 1 .}$

\begin{tabular}{ccc}
\hline Compounds & Name & IC $_{\mathbf{5 0}}$ \\
\hline $\mathbf{1}$ & Cordidepsine & $\sim 4.65$ \\
$\mathbf{1 1}$ & Allantoin & $\sim 412.94$ \\
Reference & Chicoric acid & 0.33
\end{tabular}

$\mathrm{IC}_{50}: 50 \%$ inhibitory concentration, that is, the concentration of extract/compound that inhibits by $50 \%$ the activities of the enzyme.

\subsubsection{Antimicrobial Activity}

The different extracts and fractions were tested for their antimicrobial activities (Table 4). EtOAc extracts of roots and stem barks showed good and significant activity against Gram positive bacteria (Bacillus subtilis and Staphylococcus aureus). These samples were inactive on Gram negative (Escherichia coli, Pseudomonas aeruginosa and Salmonella typhi) whereas EtOAc extract of leaves was not active against all these tested bacteria. This result is in concordance with the previous studies which revealed that species of Cordia genus are potential antibacterial agents [9]. The stem bark ethanolic extract of C. alliodora, neutral fraction of leaves of C. cylindrostachya, leaves and flowers methanolic extracts of $C$. boissieri exhibited antimicrobial activity against Gram positive and negative bacteria [9]. Furthermore, previous studies reported that betulinic acid (6), lupenone (7), lupeol (9) and $\beta$-amyrin (10) exhibit antibacterial activities [31-33] and these reported findings might also explain the observed activities of the extracts.

Table 4. In vitro antibacterial activity of Cordia millenii.

\begin{tabular}{ccccccc}
\hline & \multirow{2}{*}{ Code } & \multicolumn{4}{c}{ Microorganisms Tested a $^{\text {a }}$} \\
\cline { 3 - 6 } & & E. coli & B. subtilis & S. aureus & P. aeruginosa $^{\text {S. typhi }}$ \\
\hline EtOAc fraction of roots & RCM-A & NI & 49.45 & NI & NI & NI \\
EtOAc extract of stem barks & TCM-H & NI & NI & 65.2 & NI & NI \\
EtOAc fraction of leaves & FCM & NI & NI & NI & NI & NI \\
Reference & Tetracycline & - & 92.00 & 89.00 & - & - \\
\hline
\end{tabular}

a The data are represented as percentage (\%) of inhibition; NI: No Inhibition.

\subsubsection{Cytotoxicity Activity}

The percentage cell viability of ethyl acetate extract of stem barks, ethyl acetate fraction of roots and leaves were 99\%, 96\% and 95\% respectively, compared to reference (Cyclohexamide 93\%). Based on these findings, all these extracts did not exhibit obvious cytotoxicity activity against 3T3 cell (Human cells) and therefore, were not submitted to further $\mathrm{IC}_{50}$ studies. To the best of our knowledge, this is the first report on the toxicity profile of Cordia millenii, Baker in the literature.

\section{Materials and Methods}

\subsection{General Experimental Procedures}

The NMR spectra $\left({ }^{1} \mathrm{H}\right.$ and $\left.{ }^{13} \mathrm{C}\right)$ were recorded on four different Bruker instruments including $400 \mathrm{MHz}, 500 \mathrm{MHz}, 600 \mathrm{MHz}, 800 \mathrm{MHz}$. Chemical shifts are given in $\delta$ (ppm) value relative to TMS as internal standard. Deuterated solvents were used to dissolve the samples for NMR experiments. The HR-ESI-MS spectra were obtained from Bruker Compact QToF and MAXIS II mass spectrometers. EI-MS and FAB-MS data were recorded on a Jeol JMS HX 110 mass spectrometer. Silica 
gel (230-400 meshes) was used for column chromatography. Thin Layer Chromatography (TLC) and preparative TLC were performed on precoated silica gel plates ( $60 \mathrm{~F}_{254}$, Macherey-Nagel) using various solvent systems as eluent. Spots were visualized using UV light ( $\lambda_{\max } 254$ and $\left.366 \mathrm{~nm}\right)$ and diluted sulphuric acid (10\%).

\subsection{Plant Materials}

The plant materials (leaves, stem bark and root) of Cordia millenii, Baker were collected from Batoufam, in the West region of Cameroon in May 2015. A voucher specimen ( $\left.\mathrm{N}^{\circ} 35142 / \mathrm{HNC}\right)$ was deposited in the National Herbarium of Cameroon in Yaoundé.

\subsection{Extraction and Isolation of Compounds from Cordia millenii Plant Materials}

The stem bark powder $(1.85 \mathrm{~kg})$ was extracted by maceration at room temperature for $72 \mathrm{~h}$ with three different solvents, that is, $n$-hexane, EtOAc and $\mathrm{MeOH}$, successively. The EtOAc extract (35 g) was subjected to column chromatography (CC) over silica gel, eluted with $n$-hexane, EtOAc and $\mathrm{MeOH}$ in the increasing order of polarities to afford 20 fractions. Fraction $1(90 \mathrm{mg})$ was purified by CC over silica gel with $n$-hexane/ $\mathrm{CH}_{2} \mathrm{Cl}_{2}(4: 6, v / v)$ to afford two subfractions $\left(\mathrm{SF}_{1}\right.$ and $\left.\mathrm{SF}_{2}\right) . \mathrm{SF}_{1}(44.8 \mathrm{mg})$ and $\mathrm{SF}_{2}(35.6 \mathrm{mg})$ were purified by CC over silica gel and eluted with $n$-hexane/EtOAc $(9.2: 0.8, v / v)$ and (8.5:1.5, v/v), respectively. $\mathrm{SF}_{1}$ gave lupeol (9) (22 mg) and $\beta$-amyrin (10) (12 mg). $\mathrm{SF}_{2}$ afforded lupenone (7) (44 mg) and $\beta$-amyrone (8) (10 mg). Successive CC followed by preparative TLC of fraction 3 (20 mg) using $n$-hexane/EtOAc (6:4,v/v) afforded cordidepsine (1) $(2.7 \mathrm{mg})$. 1-(26-hydroxyhexacosanoyl)glycerol (4) $(23.6 \mathrm{mg})$ was obtained by purification of fraction $4(31.2 \mathrm{mg})$ in $n$-hexane/EtOAc $(1: 1, v / v)$. Fraction $5(80 \mathrm{mg})$ was purified by CC over silica gel and eluted with EtOAc/MeOH $(9: 1, v / v))$ to give allantoin (11) (52 mg).

The roots powder $(2.44 \mathrm{~kg})$ was extracted by maceration at room temperature for $72 \mathrm{~h}$ with $\mathrm{MeOH}$. The crude extract (185.6 g) was partitioned with $n$-hexane and EtOAc. The EtOAc fraction (50.23 g) was subjected to CC over silica gel eluted with $n$-hexane, EtOAc and MeOH in the increasing order of polarities to afford 4 subfractions. The precipitation of subfraction 1 (40.4 $\mathrm{mg})$ in $n$-hexane led to cyclooctasulfur (2) (38.2 mg) after purification. Subfraction $3(70.5 \mathrm{mg})$ was purified by CC and eluted with $n$-hexane/EtOAc $(8.5: 1.5, v / v)$ and $(7.5: 2.5, v / v)$ to give betulinic acid (6) (11 mg) and glyceryl-1-hexacosanoate (5) (20 mg), respectively.

The powder from leaves $(2.45 \mathrm{~kg})$ was extracted by maceration at room temperature for $72 \mathrm{~h}$ in $\mathrm{MeOH} / \mathrm{CH}_{2} \mathrm{Cl}_{2}(1: 1, v / \mathrm{v})$. The crude extract $(97.87 \mathrm{~g})$ followed the same procedure as for the root extract to yield 4 subfractions (SF). $\mathrm{SF}_{1}(13 \mathrm{mg})$ was purified by CC on silica gel with $n$-hexane/EtOAc (8.5:1.5, $v / v)$ to give lup-20(29)-en-3-triacontanoate (3) $(9.8 \mathrm{mg}) . \mathrm{SF}_{3}(16.9 \mathrm{mg})$ was purified by preparative TLC with $n$-hexane/EtOAc $(9: 1, v / v)$ to afford 2'-(4-hydroxyphenyl)ethylpropanoate (12) (12 mg). SF (60 mg) precipitated in EtOAc to afford stigmasterol glycoside (13) (35.8 mg).

\subsection{Acetylation Reaction of Compounds 4 and 5}

A mixture of $10 \mathrm{mg}$ of compound 4,1 $\mathrm{ml}$ of acetic anhydride and $1 \mathrm{ml}$ of pyridine was stirred at room temperature for $12 \mathrm{~h}$. After the end of the reaction, a normal workup procedure was followed: $10 \mathrm{~mL}$ chloroform and $10 \mathrm{~mL}$ distilled water were added to the reaction mixture, the organic layer was separated and dried under reduce pressure. The resulted product was purified by CC with $n$-hexane/EtOAc $(9: 1, v / v)$ to afford compound $14(6 \mathrm{mg})$. The same reaction conditions were applied to compound 5 to afford compound $15(4.8 \mathrm{mg})$.

\subsection{Compound Identification}

Cordidepsine (1): white powder (DMSO), HR-ESI-MS $m / z 376.4972[\mathrm{M}+2 \mathrm{Na}]^{+}$(calcd for $\left.\mathrm{C}_{17} \mathrm{H}_{14} \mathrm{O}_{7} \mathrm{Na}_{2}, 376.0535\right),{ }^{1} \mathrm{H}-\mathrm{NMR},{ }^{13} \mathrm{C}-\mathrm{NMR}, \mathrm{HMBC}$ and NOESY see Table 1.

Cordicerol $A$ (14): white powder $\left(\mathrm{CHCl}_{3}\right)$, HR-ESI-MS m/z $613.4672[\mathrm{M}+\mathrm{H}]^{+}$(calcd for $\mathrm{C}_{35} \mathrm{H}_{65} \mathrm{O}_{8}$, 613.4679), ${ }^{1} \mathrm{H}-\mathrm{NMR},{ }^{13} \mathrm{C}-\mathrm{NMR}, \mathrm{HMBC}$ and COSY see Table 2. 
Cordicerol B (15): white powder $\left(\mathrm{CHCl}_{3}\right)$, HR-ESI-MS $\mathrm{m} / z 577.4448[\mathrm{M}+\mathrm{Na}]^{+}$(calcd for $\left.\mathrm{C}_{33} \mathrm{H}_{62} \mathrm{O}_{6} \mathrm{Na}, 577.4446\right),{ }^{1} \mathrm{H}-\mathrm{NMR},{ }^{13} \mathrm{C}-\mathrm{NMR}, \mathrm{HMBC}$ and COSY see Table 2.

\subsection{HIV-1 Integrase Strand Transfer Reaction Assay}

The HIV-1 subtype $C$ integrase (CIN) strand transfer inhibition assay was adapted from previously described method [34]. $20 \mathrm{nM}$ double-stranded biotinylated donor DNA (5'-5Biotin TEG/ACCCTTTTAGTCAGTGTGGAAAATCTCTAGCA-3' annealed to 5' ACTGCTAGAGATTTTCC ACACTGACTAAAAG-3') was immobilized in wells of streptavidin coated 96-well microtiter plates (R\&D Systems, USA). Following incubation at room temperature for $40 \mathrm{~min}$ and a stringent wash step, $5 \mu \mathrm{g} / \mathrm{mL}$ purified recombinant HIV-1 CIN in buffer $1(50 \mathrm{~mm} \mathrm{NaCl}, 25 \mathrm{mM}$ Hepes, $25 \mathrm{mM}$ $\mathrm{MnCl}_{2}, 5 \mathrm{mM} \beta$-mercaptoethanol, $50 \mu \mathrm{g} / \mathrm{mL}$ BSA, $\mathrm{pH}$ 7.5) was added to individual wells. Test samples and chicoric acid were added to individual wells to a final concentration of $20 \mu \mathrm{M}$ (pure compounds and chicoric acid) and $20 \mu \mathrm{g} / \mathrm{mL}$ (extracts). Recombinant HIV-1 subtype C IN was assembled onto the preprocessed donor DNA through incubation for $45 \mathrm{~min}$ at room temperature. Strand transfer reaction was initiated through the addition of $10 \mathrm{nM}$ (final concentration) double-stranded FITC-labelled target DNA (5'-TGACCAAGGGCTAATTCACT/36-FAM/-3' annealed to $5^{\prime}$ - AGTGAATTAGCCCTTGGTCA-/36-FAM/-3') in integrase buffer 2 (same as buffer 1, except $25 \mathrm{~mm} \mathrm{MnCl} 2$ replaced with $2.5 \mathrm{~mm} \mathrm{MgCl}$ ). After an incubation period of $60 \mathrm{~min}$ at $37^{\circ} \mathrm{C}$, the plates were washed using PBS containing $0.05 \%$ Tween 20 and $0.01 \%$ BSA, followed by the addition of peroxidase-conjugated sheep anti-FITC antibody (ThermoScientific, USA), diluted 1:1000 in the same PBS buffer. Finally, the plates were washed and peroxidase substrate (Sure Blue Reserve ${ }^{\mathrm{TM}}, \mathrm{KPL}, \mathrm{USA}$ )

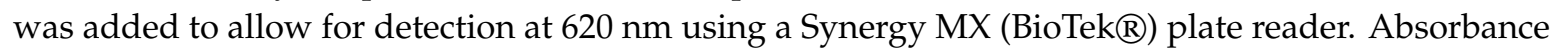
values were converted to percentage enzyme activity relative to the readings obtained from control wells (enzyme without inhibitor).

\subsection{Antibacterial Activity}

This assay was used to screen the antibacterial activity of the extracts and it was evaluated using the microplate alamar blue method [35,36]. Organisms, grown in Mueller Hinton medium (Oxoid Limited, UK), were inoculated in Mueller Hinton Broth (MHB) (Oxoid Limited, UK) and were incubated overnight at $37^{\circ} \mathrm{C}$. Fully grown turbid bacterial cultures were then diluted to adjust with $0.5 \mathrm{McF}$ arland Turbidity Index (equivalent to $1.5 \times 10^{8} \mathrm{CFU} / \mathrm{mL}$ ). Stock solutions $(60 \mathrm{mg} / \mathrm{mL})$ of different extracts were prepared in DMSO and $10 \mu \mathrm{L}$ each of these stock solutions were placed in wells of flat bottom, polystyrene, sterile 96-wells micro titer plate except the positive control wells (media + bacteria). This gave $3000 \mu \mathrm{g} / \mathrm{mL}$ concentrations of extracts in the final $200 \mu \mathrm{L}$ solution. Finally, bacterial suspension $\left(3 \times 10^{6} \mathrm{CFU} / \mathrm{mL}\right)$ was added in each well. Plates were sealed with parafilm and incubated at $37^{\circ} \mathrm{C}$ for 18-24 h. Next day, $20 \mu \mathrm{L}$ of $0.02 \%$ resazurin sodium salt dye (Chem-Impex-Int' $\mathrm{L}$ Inc.) was added to each well and was incubated in a shaking incubator at $80 \mathrm{rpm}$ and $37^{\circ} \mathrm{C}$ for $2-3 \mathrm{~h}$. The color change from blue to reddish pink indicated the growth of bacteria. For quantitative analysis, plates were read at $570 \mathrm{~nm}$ and $600 \mathrm{~nm}$ in a Multiskan ${ }^{\mathrm{TM}}$ GO microplate spectrophotometer, (ThermoScientific, USA). The $\%$ inhibition of bacterial growth was calculated using the formula:

$\%$ inhibition $=100-(\%$ difference in the reduction between treated and positive control bacteria $)$

\subsection{Cytotoxicity Activity}

It was evaluated in 96-well flat-bottomed micro plates by using the standard MTT (3-[4, 5-dimethylthiazole-2-yl]-2, 5-diphenyl-tetrazolium bromide) colorimetric assay [37]. For this purpose, 3T3 (mouse fibroblast) cells were cultured in Dulbecco's Modified Eagle Medium, supplemented with $5 \%$ of fetal bovine serum (FBS), $100 \mathrm{IU} / \mathrm{mL}$ of penicillin and $100 \mu \mathrm{g} / \mathrm{mL}$ of streptomycin in $75 \mathrm{~cm}^{2}$ flasks and kept in $5 \% \mathrm{CO}_{2}$ incubator at $37^{\circ} \mathrm{C}$. Exponentially growing cells were harvested, counted with a hemocytometer and diluted with a particular medium. Cell culture with the concentration of $5 \times 10^{4}$ cells $/ \mathrm{mL}$ was prepared and introduced $(100 \mu \mathrm{L} /$ well $)$ into 96 -well plates. After overnight 
incubation, medium was removed and $200 \mu \mathrm{L}$ of fresh medium was added with different concentration of compounds $(1-30 \mu \mathrm{M})$. After $48 \mathrm{~h}, 200 \mu \mathrm{L}$ MTT $(0.5 \mathrm{mg} / \mathrm{mL})$ was added to each well and incubated further for $4 \mathrm{~h}$. Subsequently, $100 \mu \mathrm{L}$ of DMSO was added to each well. The extent of MTT reduction to formazan within cells was calculated by measuring the absorbance at $540 \mathrm{~nm}$, using a micro plate reader (Spectra Max plus, Molecular Devices, CA, USA). The cytotoxicity was recorded as concentration causing $50 \%$ growth inhibition $\left(\mathrm{IC}_{50}\right)$ for $3 \mathrm{~T} 3$ cells. The percentage inhibition was calculated by using the following formula:

$\%$ inhibition $=100-(($ mean of O.D of test compound - mean of O.D of negative control $) /($ mean of O.D of positive control - mean of O.D of negative control $\left.)^{*} 100\right)$.

\subsection{X-ray Diffraction Studies}

Crystals of compound 2 were grown by slow evaporation of methanol/chloroform solution at $293 \mathrm{~K}$. The crystal used for X-ray measurement was lamellar, with dimensions of $0.16 \times 0.07 \times 0.06 \mathrm{~mm}$. Cyclic octaatomic sulfur, $\mathrm{S}_{8}, \mathrm{M}_{\mathrm{X}}=256.48 \mathrm{~g} \cdot \mathrm{mol}^{-1}$ crystallized in the orthorhombic system, space group Fddd $(Z=16)$. The unit cell parameters were as follow: $a=10.4709(7) \AA, b=12.8709(8) \AA$ and $c=24.484(2) \AA$ with a cell volume of 3299.7(4) $\AA^{3}$. The calculated density equal to $2.065 \mathrm{mg} \cdot \mathrm{m}^{-3}$. The linear absorption coefficient was $\mu=19.279 \mathrm{~mm}^{-1}$ for the $\lambda\left(\mathrm{M}_{0} \mathrm{~K}_{\alpha}\right)$ radiation $(\lambda=1.54178 \AA)$. The diffracted intensities were collected with an ENRAF NONIUS Kappa CCD diffractometer. The structure was solved by Direct Methods (SHELXS 97) and refined by Full-matrix least-squares on $\mathrm{F}^{2}$ [38]. All sulfur atoms were refined anisotropically. The final reliability factors were $R_{1}=0.0178, w R_{2}=0.0449[I>2 \sigma(I)]$ and the goodness of fit on $\mathrm{F}^{2}$ was equal to 1.038. The maximum and minimum transmission were 0.3909 and 0.1484 , respectively.

\section{Conclusions}

Column chromatography of stem bark, roots and leaves of C. millenii led to the isolation and identification of cordidepsine (1), a new derivative of depsidone, cyclooctasulfur (2), isolated from plant source and eleven known compounds-lup-20(29)-en-3-triacontanoate (3), 1-(26-hydroxyhexacosanoyl)glycerol (4), glyceryl-1-hexacosanoate (5), betulinic acid (6), lupenone (7), $\beta$-amyrone (8), lupeol (9), $\beta$-amyrin (10), allantoin (11), 2' -(4-hydroxyphenyl)ethylpropanoate (12) and stigmasterol glycoside (13). Two derivatives of monoglycerol were hemi-synthesized through acetylation reactions to afford cordicerol A (14) and cordicerol B (15). In addition, antibacterial and cytotoxicity as well as anti-HIV-integrase activities in vitro of some samples were evaluated. Cordidepsine (1) exhibited interesting in vitro anti-HIV-integrase activity with an $\mathrm{IC}_{50}$ value of 4.65 $\mu \mathrm{M}$. The crude extracts of different parts of $C$. millenii were not toxic against 3T3 cell (human cells) while leaves samples were inactive against all tested bacteria.

Supplementary Materials: The spectra of compounds (1, 14 and 15) and crystal data of compound 2 are available online at http://www.mdpi.com/1420-3049/24/17/3202/s1. Figure S1-S22: MS and NMR spectral data of compounds 1, 14 and 15, Table S1-S4: X-ray crystallography data of compound 2.

Author Contributions: Conceptualization, R.D.Z., X.S.-N., J.T.M., R.W.M.K., M.I.C. and A.d.T.A.; Formal analysis, R.D.Z, X.S.-N., M.T.F., T.T.K. and A.d.T.A. Funding acquisition, A.d.T.A.; Investigation, R.D.Z.; Methodology, R.D.Z, X.S.-N., T.T.K., J.T.M., R.W.M.K., M.I.C. and A.d.T.A.; Resources, A.d.T.A.; Supervision, J.T.M., R.W.M.K. and M.I.C.; Writing - original draft, R.D.Z and T.T.K.; Writing - review \& editing, R.D.Z, X.S.-N., M.T.F, R.W.M.K., M.I.C. and A.d.T.A.

Funding: This research was funded by The World Academy of Sciences (TWAS) Fellowship for Research (FR number: 3240287184) for sponsoring part of this work. This research project was also supported by International Center for Chemical and Biological Sciences (ICCBS), Pakistan as well as the South African Medical Research Council (MRC) with funds from National Treasury under its Economic Competitiveness and Support Package.

Acknowledgments: The authors are grateful to The World Academy of Sciences (TWAS) Fellowship for Research to R.D.Z. and the International Center for Chemical and Biological Sciences (ICCBS) Pakistan for welcoming R.D.Z. The authors also thank Bertha Chithambo and Dominique Ngono Bikoko for proof-reading this manuscript. 
Conflicts of Interest: The authors declare no conflict of interest. The funders had no role in the design of the study; in the collection, analyses or interpretation of data; in the writing of the manuscript or in the decision to publish the results.

\section{Abbreviations}

$\mathrm{AC}_{2} \mathrm{O}$, Acetic anhydride; $\mathrm{CC}$, Column Chromatography, $\mathrm{CDCl}_{3}$, Chloroform-deuterated; $\mathrm{CH}_{2} \mathrm{Cl}_{2}$, Dichloromethane; COSY, Correlation Spectroscopy; EI, Electronic Impact; HR-ESI, High Resolution Electrospray Ionization; DEPT, Distortionless Enhancement by Polarization Transfert, DMSO, Dimethyl sulfoxide; EtOAc, Ethyl Acetate; FAB, Fast Atom Bombardment; HMBC, Heteronuclear Multiple Bond Correlation; HNC, Herbier National du Cameroun (i.e. National herbarium of Cameroon); HR, High Resolution; HSQC, Heteronuclear single Quantum Correlation; MeOH, Methanol; MS, Mass Spectroscopy; NOESY, Nuclear Overhauser Effect Spectroscopy; TLC, Thin layer Chromatography; 1D-and 2D-NMR, one dimension and two dimensions nuclear magnetic resonance; $v / v$, volume by volume.

\section{References}

1. Siwe-Noundou, X.; Musyoka, T.M.; Vuyani, M.; Ndinteh, D.T.; Mnkandhla, D.; Hoppe, H.; Özlem, T.B.; Krause, R.W.M. Anti-HIV-1 integrase potency of methylgallate from Alchornea cordifolia using in vitro and in silico approaches. Sci. Rep. 2019, 9, 4718. [CrossRef] [PubMed]

2. Cameroon Population Based HIV Impact Assessment (CAMPHIA). Summary Sheet: Primilary Fundings. 2018. Available online: https//phia.icap.columbia.edu/.../3471CAMPHIACameroon-SS_A4_v13_requests_7.25.18. pdf (accessed on 2 May 2019).

3. United Nations Acquired Immune Deficiency Syndrome (UNAIDS). HIV-Related Opportunistic Diseases: UNAIDS Technical Update. 1994. Available online: http://data.unaids.org/publications/irc-pub05/opportu_en. pdf (accessed on 2 May 2019).

4. World Health Organization (WHO). WHO Model Prescribing Information-Drugs Used in Bacterial Infections; WHO: Geneva, Switzerland, 2001; pp. 1-165. Available online: http://www.who.int/iris/handle/10665/42372. pdf (accessed on 02 May 2019).

5. Cordia millenii (Prota). Fiche de Protabase (Ressources végétales de l'Afrique tropicale). 2010. Available online: http://uses.plantnet-project.org/en/Cordia_millenii_(prota) (accessed on 25 May 2019).

6. Focho, D.A.; Muh, C.N.; Mendi, G.A.; Fongod, A.N.; Fonge, B.A. Ethnobotanical survey of trees in Fundong, Northwest Region, Cameroon. J. Ethnobiol. Ethnomed. 2009, 5, 1-12. [CrossRef]

7. Ezeonu, C.S.; Ejikeme, C.M. Qualitative and quantitative determination of phytochemical contents of indigenous Nigeria softwoods. New J. Sci. 2016, 2016, 1-9. [CrossRef]

8. Moir, M.; Thomson, R.H.; Hausen, B.M.; Simatupa, M.H. Cordiachromes: A new group of terpenoid quinones from Cordia spp. J. Chem. Soc. 1972, 166, 363-364. [CrossRef]

9. Oza, M.; Kulkarni, Y.A. Traditional uses, phytochemistry and pharmacology of the medicinal species of the genus Cordia (Boraginaceae). J. Pharm. Pharmacolo. 2017, 69, 755-789. [CrossRef] [PubMed]

10. Pandey, R.; Kaur, R.; Malasoni, R.; Gupta, M.M. Lupeol ester from Clerodendrum phlomidis L. Indian J. Chem. 2008, 4B, 470-472. [CrossRef]

11. Babady-Byla; Werner, H. Triterpenes and 1-( $\omega$-hydroxyceratyl)glycerols from pentaclethra eetveldeana root bark. Phytochemistry 1996, 42, 501-504. [CrossRef]

12. Djemgou, P.C.; Gatsing, D.; Tchuendem, M.; Ngadjui, B.T.; Tane, P.; Ahmed, A.A.; Gamal-Eldeen, A.M.; Adoga, G.I.; Hirata, T.; Mabry, T.J. Antitumor and immunostimulatory activity of two chromones and other constituents from Cassia petersiana. Nat. Prod. Comm. 2006, 1, 961-968. [CrossRef]

13. Shahlaei, M.; Ghanadian, S.M.; Ayatollahi, A.M.; Mesaik, M.A.; Abdalla, O.M.; Afsharypour, S.; Rabbani, M. Molecular modeling, structure activity relationship and immunomodulatory properties of some lupeol derivatives. Med. Chem. Res. 2013, 22, 1795-1803. [CrossRef]

14. Rao, G.V.; Annamalai, T.; Mukhopadhyay, T. Chemical examination and biological studies on the bark of Crataeva nurvala. Pharmacogn. J. 2011, 3, 1-4. [CrossRef]

15. Begum, F.; Nahar, S.K.; Rashid, M.A. Secondary metabolites from different extractives of Stereospermum suaveolens. Dhaka Univ. J. Pharm. Sci. 2014, 13, 31-36. [CrossRef]

16. Malca Garcia, G.R.; Hennig, L.; Sieler, J.; Bussmann, L. Constituents of Corynaea crassa "Peruvian Viagra". Braz. J. Pharmacogn. 2015, 25, 92-97. [CrossRef] 
17. Okeye, N.N.; Ajaghaku, L.D.; Okeke, H.H.; Ilodigwe, E.E.; Nworu, C.S.; Okeye, F.B.C. Beta-amyrin and alpha-amyrin acetate isolated from the stem bark of Alstonia boonei display profound anti-inflammatory activity. Pharm. Biol. 2014, 52, 1478-1486. [CrossRef] [PubMed]

18. Wang, H.Z.; Wang, C.J. Isolation, characterization and analgesic activity of natural allantoin from Portulaca oleracea seed. Mod. Chem. Appl. 2018, 8, 1-3. [CrossRef]

19. Aissa, I.; Sghair, R.M.; Bouaziz, M.; Laouini, D.; Sayadi, S.; Gargouri, Y. Synthesis of lipophilic tyrosyl esters derivatives and assessment of their antimicrobial and antileishmania activities. Lipids Health Dis. 2012, 11, 1-8. [CrossRef] [PubMed]

20. Ridhay, A.; Noor, A.; Soekamto, N.H.; Harlim, T.; Altena, I.V. A stigmasterol glycoside from the root wood of Melochia umbellata (Houtt) Stapf var. degrabrata K. Indo. J. Chem. 2012, 12, 100-103. [CrossRef]

21. Ouyang, J.; Mao, Z.; Guo, H.; Xie, Y.; Cui, Z.; Sun, J.; Wu, H.; Wen, X.; Wang, J.; Shan, T. Mollicellins O-R, four new depsidones isolated from the endophytic fungus Chaetomium sp. Eef-10. Molecules 2018, 23, 3218. [CrossRef]

22. Dong-Lin, Z.; Chang-Lun, S.; Chao-Yin, W.; Mei, W.; Lu-Jia, Y.; Chang-Yun, W. Naphthalenones and depsidones from a sponge-derived strain of the fungus Corynespora cassiicola. Molecules 2016, 21, 160. [CrossRef]

23. Chen, S.; Liu, Z.; Lui, Y.; Lu, Y.; He, L.; She, Z. New depsidones and isoindolinones from the mangrove endophytic fungus Meyerozyma guilliermondii $\left(\mathrm{HZ}-\mathrm{Y}_{2}\right)$ isolated from the South China Sea. Beilstein J. Org. Chem. 2015, 11, 1187-1193. [CrossRef]

24. Varughese, T.; Riosa, N.; Higginbotham, S.; Arnold, E.A.; Coley, P.D.; Kursar, T.A.; Gerwick, W.H.; Cubilla Rios, L. Antifungal depsidone metabolites from Cordyceps dipterigena and endophytic fungus antagonistic to the phytopathogen Gibberella fujikuroi. Tetrahedron Lett. 2012, 53, 1624-1626. [CrossRef]

25. Ngoupayo, J.; Tabopda, K.T.; Shaiq, M.A.; Tsamo, E. $\alpha$-Glucosidase inhibitors from Garcinia brevipedicellata (Clusiaceae). Chem. Pharm. Bull. 2008, 56, 1466-1469. [CrossRef]

26. Jeannerat, D. Rapid multidimensional NMR: High resolution by spectral aliasing. Encycl. Magn. Reson. 2011. [CrossRef]

27. Pastorino, C.; Gamba, Z. Test of a simple and flexible $\mathrm{S}_{8}$ model molecule in $\alpha-\mathrm{S}_{8}$ crystals. Chem. Phys. Lett. 2000, 319, 20-26. [CrossRef]

28. Hapuarachchi, K.K.; Wen, T.C.; Jeewon, R.; Wu, X.L.; Kang, J.C. Mycosphere Essays 15. Ganoderma lucidum-Are the beneficial medical properties substantiated? Mycosphere 2016, 7, 687-715. [CrossRef]

29. Nicklaus, M.C.; Neamati, N.; Hong, H.; Mazumder, A.; Sunder, S.; Chen, J.; Milne, G.W.A.; Pommier, Y. HIV-integrase pharmacophore: Discovery of inhibitors through three-dimensional database searching. J. Med. Chem. 1997, 40, 920-929. [CrossRef] [PubMed]

30. Neamati, N.; Hong, H.; Mazumder, A.; Wang, S.; Sunder, S.; Nicklaus, M.C.; Milne, G.W.A.; Proksa, B.; Pommier, Y. Depsines and depsidones as inhibitors of HIV-1 integrase: Discovery of inhibitors through 3D database searching. J. Med. Chem. 1997, 40, 942-951. [CrossRef] [PubMed]

31. Shai, L.J.; McGaw, L.J.; Aderogba, M.A.; Mdee, L.K.; Eloff, J.N. Four pentacyclic triterpenoids with antifungal and antibacterial activity from Curtisia dentata (Burm.f) C.A. Sm. leaves. J. Ethnopharm. 2008, 119, 238-244. [CrossRef] [PubMed]

32. Abdel-Raouf, N.; Al-Enazi, N.M.; Al-Homaidan, A.A.; Ibraheem, I.B.M.; Al-Othman, M.R.; Hatamleh, A.A. Antibacterial $\beta$-amyrin isolated from Laurencia microcladia. Arabian J. Chem. 2015, 8, 32-37. [CrossRef]

33. Po-Wei, T.; De castro-Cruz, K.A.; Chien-Chang, S.; Ragasa, C.Y. Chemical constituents of Broussonetia luzonicus. Pharmacogn. J. 2012, 4, 1-4. [CrossRef]

34. Siwe-Noundou, X.; Ndinteh, D.T.; Olivier, D.K.; Mnkandhla, D.; Isaacs, M.; Muganza, F.M.; Mbafor, J.T.; Van Vuuren, S.F.; Patnala, S.; Hoppe, H.; et al. Biological activity of plant extracts and isolated compounds from Alchornea laxiflora: Anti-HIV, antibacterial and cytotoxicity evaluation. S. Afr. J. Bot. 2018, 122, 498-503. [CrossRef]

35. Pettit, R.K.; Weber, C.A.; Kean, M.J.; Hoffmann, H.; Pettit, G.R.; Tan, R.; Franks, K.S.; Horton, M.L. Microplate alamar blue assay for Staphylococcus epidermidis biofilm susceptibility testing. Antimicrob. Agents Chemother. 2005, 49, 2612-2617. [CrossRef] [PubMed]

36. Sarkar, S.D.; Nahar, L.; Kumarasamy, Y. Microtitre plate-based antibacterial assay incorporating resazurin as an indicator of cell growth and its application in the in vitro antibacterial screening of phytochemicals. Methods 2007, 42, 321-324. [CrossRef] [PubMed] 
37. Mosmann, T. Rapid colorimetric assay for cellular growth and survival: Application to proliferation and cytotoxicity assays. J. Immunol. Methods 1983, 65, 55-63. [CrossRef]

38. Sheldrick, G.M. SHELX-97. Cryst. Struct. Refinement 1997, 199.

Sample Availability: Samples of the compounds 3-13 are available from the authors. 